\title{
A Match or Mismatch Between Learning Styles of the Learners and Teaching Styles of the Teachers
}

\author{
Abbas Pourhosein Gilakjani \\ Department of English Language Translation, Lahijan Branch, Islamic Azad University, Lahijan, Iran \\ Email: a_p_g48@yahoo.com
}

\begin{abstract}
It is important to study learning styles because recent studies have shown that a match between teaching and learning styles helps to motivate students' process of learning. That is why teachers should identify their own teaching styles as well as their learning styles to obtain better results in the classroom. The aim is to have a balanced teaching style and to adapt activities to meet students' style and to involve teachers in this type of research to assure the results found in this research study. Over 100 students complete a questionnaire to determine if their learning styles are auditory, visual, or kinesthetic. Discovering these learning styles will allow the students to determine their own personal strengths and weaknesses and learn from them. Teachers can incorporate learning styles into their classroom by identifying the learning styles of each of their students, matching teaching styles to learning styles for difficult tasks, strengthening weaker learning styles. The purpose of this study is to explain learning styles, teaching styles match or mismatch between learning and teaching styles, visual, auditory, and kinesthetic learning styles among Iranian learners, and pedagogical implications for the EFL/ESL classroom. A review of the literature along with analysis of the data will determine how learning styles match the teaching styles.
\end{abstract}

Index Terms - Learning styles, Teaching styles, Match, Mismatch, Implications

\section{INTRODUCTION}

Learning styles are various ways of learning [1]. They involve educating methods that are presumed to allow an individual to learn best. Most people prefer an identifiable method of interacting with, taking in, and processing stimuli or information. Based on this concept, the idea of individualized "learning styles" acquired "enormous popularity [2]. Proponents say that teachers should assess the learning styles of their students and adapt their classroom methods to best fit each student's learning style [3], [4]. Although children and adults express personal preferences, there is no evidence that identifying a student's learning style produces better outcomes, and there is significant evidence that the widespread "meshing hypothesis" (that a student will learn best if taught in a method deemed appropriate for the student's learning style) is invalid [2]. Well-designed studies "flatly contradict the popular meshing hypothesis [2]. However, this research does not mean that individuals do not have learning preferences, or that they will not learn better if the teaching technique does not take account of these techniques, and teaching methods that provide preferential treatment to one group in the classroom is likely to produce significantly sub-optimal results.

Two major hypotheses about learning styles have been proposed by [5]. They are as follows:

1. all students have their own learning styles and learning strengths and weaknesses.

2. a mismatch between teaching and learning styles causes learning failure, frustration and demotivation.

EFL teachers should consider the students' learning styles and their own teaching styles which show their favored learning styles. Without this knowledge, clashes would affect students' learning potential and their attitudes toward learning. Both the teachers and students should be aware of their styles and try to harmonize them [5], [6]. According to [4] teachers should assess the learning styles of their students and adapt their classroom methods to best fit each student's learning style. Teaching and learning styles are the behaviors or actions that teachers and learners show in the learning exchange. Teaching behaviors show the beliefs and values that teachers hold about the learners' role in the exchange [7]. Behaviors provide insight into the ways learners perceive, interact with, and respond to the environment in which learning occurs [8]. Questions about the congruence of teaching and learning styles have surfaced: Do the teaching styles of teachers match students' learning styles? Can individuals learn effectively when instructional delivery does not match their preferred learning style? Can teaching and learning styles be adapted or modified? In this paper, the researcher explains learning styles, reviews teaching styles, discusses about match or mismatch between learning and teaching styles, analyze visual, auditory, and kinesthetic 
learning styles among Iranian learners, and states pedagogical implications for the EFL/ESL classroom.

\section{LEARNING STYLES}

Learning styles may be defined in multiple ways, depending upon one's perspective. Here are a few definitions of learning styles. Learning styles are the manners in which individuals perceive and process information in learning situations. Learning style preference is one aspect of learning style, and refers to the choice of one learning situation or condition over another [9]. Learning styles are the general approaches - for example, global or analytic, auditory or visual - that students use in acquiring a new language or in learning any other subject. The manner in which a learner perceives, interacts with, and responds to the learning environment [10]. Learning style is sometimes defined as the characteristic cognitive, affective, social, and physiological behaviors that serve as relatively stable indicators of how learners perceive, interact with, and respond to the learning environment [11].

\section{TEACHING STYLES}

Is it of vital importance that the teacher is proficient in the content area of which the instruction is being presented? According to [12] being proficient is not enough. The teacher must also possess personality traits that show an image of caring, trust, and genuine concern for the individual student. A teacher should possess the following three specific areas of knowledge: knowledge of the content specific to the instruction, knowledge of the learners, and knowledge of the teaching methods to be used [12].

Teachers should be able to recognize their philosophical orientation pertaining to education and show their individual beliefs to shape the content and scope of what they will teach [13]. It is important for every teacher to have a personal philosophy of education, because these beliefs form some of the foundations for selecting instructional content, developing lesson plans, interacting with students, and being able to assess the learning outcomes. Teachers have a wide variety of backgrounds when it comes to their educational beliefs, or what they believe is their educational philosophy. These beliefs about how to teach, what to learn, and why learners learn, set the preliminary stage for facilitating learning. Being able to understand one's own educational philosophy can have a number of benefits such as:

1. Being able to develop methods of critical thinking [13].

2. Being able to expand one's vision by enhancing personal meaning pertaining to adult education [13].
3. Being able to recognize and resolve conflicts between one's total life philosophy and one's educational philosophy [13].

4. Providing insight into the relationships deemed critical to adult education such as: Student/teacher interaction, and the relevance of the subject matter to the learner and to the world in general [13].

How does one formulate an educational philosophy? A general guideline has been proposed by [14] that teachers can follow to develop their own personal "working" philosophy on education. Teachers show their present working philosophy and build on it as needed, or whenever conflicting personal beliefs warrant it. A framework has been developed by [14] that teachers can identify with in a systematic way on their beliefs relating to education. This framework includes four elements: a reflection on our own beliefs about learners and the learning process, the goals or aspirations that we are striving for as a teacher, beliefs about the subject matter and how that content is presented from a teaching perspective, and beliefs about the student and the learning experience as it relates to instructional objectives and learning goals.

Teachers have their own preferences in terms of the teaching styles that they may want to practice and call upon throughout the lesson in order to enhance group movement and learning. Te effectiveness of the teaching and learning process depends on the excellence of the teacher in class which means that teacher is the one who is responsible in ensuring and determining the success of their teaching and in ensuring that the students understand their lesson well. There is also a need to change the educational conditions in order to meet learning style preferences of the students this action could produce statistically significant improvements in grades and attitudes of the students. By expanding and varying the teaching style, language instructors can provide opportunities for students with different learning styles to increase their learning [15]. A recommendation has been made by [16] to the instructors to identify the learning styles of the students as well as their teaching styles and then vary their teaching methods to meet the range of learners' preferences.

According to [5] all teachers have their own teaching styles. $90 \%$ of secondary school teaching is geared to auditory learners only and this has being the proportion of teacher of talk and discussion teaching style. Teachers should move away from the idea that our way of our learning or teaching is the best and to try to vary their teaching styles so that it will fit the learners' learning styles and preferences. On the origin of teaching styles, it has been proposed that teachers teach in the way they were taught or learned best or imitate the teaching styles of teachers they admired. 


\section{MATCHING TEACHING STYLES TO LEARNING STYLES}

There are four important questions that need to be explored before deciding on how to match teaching style to learning style theories in the classroom [17].

\section{A. What Are We Matching?}

There are a number of learning style instruments and a number of teaching style instruments that can be used to measure and determine compatibility between the teacher and the learner. In some cases the same instrument is used to describe both the teacher and the learner which defines what is being matched. In other cases, separate instruments are used for the learner and for the teacher, and if the instruments are good, they will measure the same dimensions and comparative data can be easily matched. Problems can arise when measured data from one instrument must be correlated with the data from another instrument which results in a close match.

\section{B. What Is the Purpose of Learning?}

If a person needs to learn quickly how to operate a new piece of equipment, every effort should be made to try to match the method of instruction to that person's learning style. One-on-one instruction makes this possible, but in a classroom situation where there are numerous learning styles, it is not possible for the instructor to accommodate all styles. In this case, the learner needs to become more resourceful by trying to align more closely to the style of the teacher. There may still be a noticeable mismatch between the learner and the teacher but matching learning style to teaching style is always the best approach.

\section{What Effect Does the Learning Content Have?}

Learners need to develop flexibility within their learning style. Most learning situations will probably require more than one learning style and at times the learner could be penalized by not being able to adapt or adjust to the learning style required to learn or understand the content.

\section{What Is the Evidence That Matching Works?}

Results of past research [18] into matching teaching styles to learning styles have been as varied as the measurement instruments themselves. Some researchers have found reliability problems with Dunn and Dunn and Price's Learning Style Inventory (LSI) [18]. Other researchers have found little or no evidence that matching teaching methods to learning methods improves the learning outcome [18]. One reason for such variety could have been that past researchers made different assumptions about the purpose of learning and the effects of the learning content. Another reason could have been that researchers failed to take into account other individual differences beyond what is typically referred to as learning styles and how those differences could affect learning. While there are no conclusive results and inconsistencies exists as to whether a "matching" style produces better results than another style, studies have shown that a person with one particular style will outperform others regardless of the teaching method used [19].

\section{DO TEACHERS TEACH THE WAY THEY HAVE BEEN TAUGHT OR LEARNT BEST?}

The majority of teachers teach the way they learn [20]. Since many teachers have experienced an academic success in learning environments that were instructor-centred and relied heavily on lecture, it is understandable that their preferred style of teaching would be to repeat what worked with them. These teachers are field independent, that is, they are more content oriented and prefer to use more formal teaching methods, favouring less student involvement and more structured class activities [21], [22]. This style works especially well for field-dependent students who want to be told what they should learn and given the resources to acquire the specified body of knowledge or skills. This may be why most training is provided through instructor-led classrooms in the corporate environment [23]. This strategy can be effective when employees are highly motivated to learn specific content that is relevant to their careers. However, instructor-centred training is not as effective when training involves context the physical, emotional, and intellectual environment that surrounds an experience and gives it meaning.

One reason teachers are led to teach the way they learn is that they are not skilled in adult learning theory. This is particularly true for trainers who have little education about and understanding of adult learning principles. Classroom teachers who are skilled in adult learning principles and have experience with theories about student-centered learning and constructivism are more likely to adopt student-centered instruction [24], even if it is not the way they learned or prefer to learn. These teachers have broad views of how teaching can occur and strong beliefs about the need to engage learners in the learning process. They are aware of the changing demographics of classrooms and the influence of technology on students' ways of learning [25], [26]. They are more likely to substitute selfdirected learning opportunities and interactive learning environments for the traditional lecture and make use of varied resources to create personally meaningful educational experiences [25].

\section{CAN AN INDIVIDUAL'S APPROACH TO LEARNING BE MODIFIED?}

Because learning is an ongoing process, occurring over the span of one's lifetime and delivered by a variety of teachers with a variety of teaching styles in a variety of situations, learners need to be able to adjust their cognitive styles. They need to become better allaround learners by investing extra effort in underdeveloped or underutilized styles [27]. Studies have been reported by [28] that explore the feasibility 
of promoting learner adaptability through training. These researchers discovered that students whose cognitive styles were more field dependent were able to change the strength of their style through training which suggests that cognitive style may be a flexible construct and malleable over the long term. These views were also noted by [21], who contend that exposing learners to learning activities that are mismatched with their preferred learning style will help them develop the learning competencies necessary to cope with situations involving a range of different learning requirements (p. 3).

\section{CAN A TEACHER'S APPROACH TO TEACHING BE MODIFIED?}

How teachers choose their teaching strategies and implement techniques is a function of their beliefs and values regarding the methods and can be modified to fit within the unique belief system of the teacher. The manner in which any method, discovery-based learning or discussion is used within a learning event is the choice of the teacher and should be a reflection of his or her philosophy [7]. Therefore, before teachers can attempt to develop more flexible teaching styles, they must be receptive to the idea of change, beginning with a change in their beliefs about the students' role in the learning environment. Being student-centered engages teachers in a humanistic approach to education in which they function as facilitators of learning [29]. Teachers who desire to be more student-centered must be aware of the kinds of learning experiences that students most value, as these may differ depending on the learners' particular stages of development, age, and gender [30]. In studying a group of international students in a business administration program, [8] found that of primary interest to students was establishing warm personal relationships with their teachers. Their preferred style of learning was to have direct contact with materials, topics, or situations being studied. Knowing this type of information can help teachers develop course structures that provide a better fit between instructional goals and students' learning style preferences [20].

\section{MATCH OR MISMATCH BETWEEN LEARNING AND TEACHING STYLES}

Finding of studies on English language learning indicated that in order to be effective ESL/EFL teachers, one should have knowledge about the learners' learning needs, individual differences in learning, the required teaching methods, learners' preferences as well as the necessary teaching materials required to meet learners' needs in the educational setting [32], [33], [37], [31], [34], [36], [38], [35]. Emphasis has also been paid to teaching and learning styles. Most of the research on teaching and learning styles has been cross-sectional in nature; many deal with the learning styles of students in higher institutions of learning. Frequently the studies focus on how demographic variables such as gender, age, university major, and personality influence learning styles [39], [35]. The learning style concept must be studied in depth for three main reasons. Firstly, it is clear that learners have their own preferences regarding learning and certain types of psychological characteristics are associated in certain "types" of individual [40], [41]. Secondly, there is evidence showing that the attempt to provide different learning styles may help learners achieve better results [33], [36]. Finally, teachers should know how to develop a classroom methodology that is based on students' learning style preferences [32], [42].

A variety of approaches have been taken in research on a link between student learning styles on the one hand and teaching styles on the other. The area of matching of student and teacher styles has been considered by [43]. They argue that more information is needed on the learning styles of large numbers of students, complemented by research geared to generating new insights into the complex interactions between learners and educators. Their study has contributed to a number of previous empirical studies that considered the matching/mismatching debate. There have been a number of such empirical studies. Teachers' orientations to teaching and student approaches to learning were correlated by [44], [45]. A Thinking Styles Inventory was applied by [38] to students and teachers to test empirically what the impact of matching/mismatching on student achievement is. A similar approach was adopted by [30] in an empirical study on aligning student learning styles with teacher styles. A student learning styles instrument was restated to shift the focus from the learner to the teacher. After testing for internal consistency and reliability, [30] study was able to compare the two groupings. The student learning styles were compared by [46] at two universities in Australia using a study process instrument. The learning styles preferences of students have been compared by [47] at two UK universities using a learning style preference instrument. Obviously, in any comparative study, careful contextualization is vital for an understanding of the findings in relation to the different locations and contexts.

Research on learning and teaching styles and specially the match or otherwise between them is still very much under researched in ESL and EFL. The findings of some studies suggest that mismatches often happen and have bad impacts on students' learning and attitudes [48], [49]. The findings of past studies stated that a learner's achievement in any class is determined by factors such as native ability, and the level of congruence between learners' learning styles and teachers' teaching styles. Many studies [33], [36] have been done to investigate the relationship between learning style and academic achievement. Matching and mismatching between teaching and learning styles exist in any academic setting, at least to a certain extent. Some studies have also found that congruence 
(matching) between teaching and learning styles has a positive impact on achievement and satisfaction [50]. A mismatch is said to occur when students' preferred methods of processing information are not aligned with the teachers' preferred styles of teaching. When mismatches exist between learning styles of most students in a class and the teaching style of the professor, the students may become bored and inattentive, do poorly on tests, get discouraged about the courses, the curriculum, and themselves, and in some cases change to other curricula or drop out of school [34].

Many learning style experts [43], [19], and [38] showed the theory that students will learn more and will enjoy the class experience and environment when they can use their preferred learning styles. In some cases, students are blamed when the classroom activity is not compatible with their way of learning. In a very recent study, suggested that teaching and learning styles should become one of the greatest interests of the educators particularly their relationship. One of the weaknesses of the research into LS is the lack of the investigation into the matching of teaching and learning styles. Many variables exist in the educational literature but few researches dealt with the matching of teaching styles and learning styles. A solution has been proposed by [17] for this situation, that is by selecting the teaching approach which will "match" different learning styles. Even though this approach sounds practical in theory, considering the diversity of student learning styles in the "real world" it is not practical within the classroom. Another solution is to identify the learners' learning styles preferences and then assist them to widen their learning styles and develop their "learning comfort factor" [52].

\section{VISUAL, AUDITORY, AND KINESTHETIC LEARNING STYLES AMONG IRANIAN LEARNERS}

In order to understand the learning preferences of Iranian EFL learners, VAK learning style model was used [53]. The VAK learning styles model suggest that most people can be divided into one of three preferred styles of learning. These three learning styles are as follows: Someone with a visual learning style has a preference for seen or observed things, including pictures, diagrams, demonstrations, displays, handouts, films, flip-chart, etc. Someone with an auditory learning style has a preference for the transfer of information through listening: to the spoken word, of self or others, of sounds and noises. Someone with a kinesthetic learning style has a preference for physical experience - touching, feeling, holding, doing, practical hands-on experiences. People commonly have a main preferred learning style, but this will be part of a blend of all three. Some people have a very strong preference; other people have a more even mixture of two or less commonly, three styles. There is no right or wrong learning style. The point is that there are types of learning that are right for our own preferred learning style.

The participants of this study were 100 students of English majoring in translation. They were 35 male and 65 female students between 21 and 25 years of age. They were studying in English Language Translation at the Islamic Azad University of Lahijan, Iran. Thirty questions with three alternatives were distributed to students. Through the processes of test administration, it was indicated that about $55 \%$ of the students preferred visual learning style, $35 \%$ of the students' preferred auditory learning style, and only $10 \%$ of the students preferred kinesthetic style for their learning. Based on the above finding, it can be concluded that the prevalent learning style among EFL students in Islamic Azad University of Lahijan, Iran was visual one and students with this type of learning style had the greatest academic achievement in their educational major. It is the responsibility of the teacher and the student to be aware of learning style preferences to improve their teaching and learning. As teachers, we need to assess and understand how to teach all students by understanding how to present information in multiple modes. We can help students more effectively both in and out of the classroom, if we are aware of their learning style and can assist them in determining their preferences. As a student, it is vital to be selfaware of preferences to adjust study techniques to best fit each individual, even when the information and instruction provided does not match the preferred style.

\section{PEDAGOGICAL IMPLICATIONS FOR THE EFL/ESL CLASSROOM}

A teacher could be very knowledgeable, creative, caring and enthusiastic yet fail to facilitate learning for students whose strengths or learning styles are not acknowledged or addressed by the teaching methods in the classroom. Results of students whose learning styles do not match those of their teachers, may not be very good or even not up to the level and therefore frustration and de-motivation would build up. Thus, it is important for teachers and students to identify and understand their preferred learning styles, respect others' styles and respond to different learning styles by accommodating some strategies that could help promote learning. The first step towards incorporating and benefiting from this research is to realize the effect of learning styles on students' learning in the ESL classroom. For teacher and students to become aware of their preferred teaching and learning styles, a learning style questionnaire or an assessment tool should be administered once the students start the course. Teachers and students should familiarize themselves with the different learning styles by addressing their strengths and weaknesses, likes and dislikes in relation to how they learn best. The identification of the learning styles would help teachers and students select and implement more effective instructional methods and materials. This should not 
imply extensive individualized instruction for every student but rather providing strategies and learning experiences to help students stretch their learning styles. This also entitles teachers to give challenging yet attainable activities that go beyond the comfort zone of the students. The more the students are exposed to different strategies the more they gain tools to use in different and various situations. Since an ESL classroom is found to be a heterogeneous one that consists of a diverse population of students with respect to discipline, gender and age, teachers cannot use specific teaching methods to address each of these variables but in light of the research in the field would find it better to change their teaching to meet the different learning styles of the students [54].

Depending on the type of course and class size, some of the following teaching strategies can be used by teachers in a class in order to encourage the learning processes:

1. Identify their own teaching styles as well as their learning styles in order to reflect about classroom practices to obtain better results in the classroom.

2. Provide challenging and novel problems to students.

2. Use examples that require analysis and synthesis.

3. Require application of information and concepts.

4. Encourage questions and discussion.

6. Combine visual, auditory, tactile, and kinesthetic techniques.

7. Balance the teaching styles and adapt activities to meet students's style.

8. Assign open-ended activities encouraging creativity.

9. Encourage tasks variation and creativity to enable learners to challenge the beliefs in the way they learn and acquire knowledge.

\section{CONCLUSION}

Although there are benefits to the matching of teaching style and learning style, it appears that this alone does not guarantee greater learner achievement. Age, educational level, and motivation influence each student's learning so that what was once preferred may no longer be the student's current preferred learning style. Teachers need to examine their belief structure regarding education and engage in an ongoing process of diagnosis, with self and with learners, including observation, questioning, obtaining evaluative feedback, and critical reflection. Each teacher is unique and can use his or her style to be as effective an educator as possible. We must understand teachers' use of learning styles and relate this to the university context. It is very important to understand and explore each individual's learning style. Analyzing one's own particular learning style can be very helpful and beneficial to the student by aiding them in becoming more focused on an attentive learner, which ultimately will increase educational success. Discovering this learning style will allow the student to determine his or her own personal strengths and weaknesses and learn from them. Teachers can incorporate learning styles into their classroom by identifying the learning styles of each of their students, matching teaching style to learning style for difficult tasks, strengthening weaker learning styles through easier tasks and drill, and teaching students, learning-style selection strategies. It is important for students to have multiple learning opportunities and "learning style-shift" and teachers should achieve a match between teaching strategies and the students' unique learning styles. Accommodating teaching to learning styles improves students' overall learning results, increases both motivation and efficiency and enables a positive attitude towards the language being learned. Teachers should have the time to develop and reinforce their expertise as well as the opportunity within the university context to spread their information, ideas, findings, and experience. Teachers should know the needs of their students as well as their necessary requirements - this is vital if learning styles are to be used in universities effectively. Determining when to use learning styles and designing good styles require real consideration and benefits from a team of people with instructional design, graphic arts, information architecture, and usability skills. Although learning styles offer teachers enormous opportunities for making learning and teaching environments meaningful and effective, learning styles by itself do not assure a good learning and teaching environment. Learning styles cannot provide the answer to the problems of resourcing, motivation, and standards in education. The purpose of using learning styles in universities is to find the best ways for both students to learn effectively and teachers to teach efficiently.

\section{ACKNOWLEDGMENT}

I thank Seyedeh Masoumeh Ahmadi, Alizadeh, and Babaee for their extensive and insightful discussions and comments on the paper.

\section{REFERENCES}

[1] LdPride. (n.d.), "What are learning styles?" Retrieved October 17, 2008.

[2] H. Pashler, M. McDaniel, D. Rohrer, and R. Bjork, "Learning styles: Concepts and evidence," Psychological Science in the Public Interest, vol. 9, pp. 105-119, 2009.

[3] R. Dunn, R, and K. Dunn, "Teaching students through their individual learning styles: A practical approach," Reston, VA: Reston Publishing Company, 1978.

[4] M. Sprenger, M. "Differentiation through learning styles and memory," Thousand Oaks, CA: Corwin Press, 2003. 
[5] J. M. Reid, "Learning styles in the ESL/EFL classroom," U.S.A: Heinle and Heinle Publishers, 1995.

[6] R. L. Oxford, M.E. Hollaway, and D. HortonMurillo, "Language learning styles: research and practical considerations for teaching in the multicultural tertiary ESL/EFL classroom," System, vol. 20, no. 4, pp. 439-456, 1992.

[7] J. E. Heimlich, and E. Norland, "Teaching Style: Where Are We Now?" New Directions for Adult and Continuing Education, no. 93, pp. 17-25, 2002.

[8] P. Ladd, and R. J. Ruby, "Learning Style and Adjustment Issues of International Students," Journal of Education for Business, vol. 74, no. 6, pp. 363-367, 1999.

[9] H. D. Brown," Principles of language teaching and learning," (4th ed.). White Plains, NY: Longman, 2000.

[10]M. Celce-Marcia," Teaching English as a second or foreign language," (3rd ed.). Dewey Publishing Services: NY, 2001.

[11]D. MacKeracher," Making sense of adult learning," (2nd ed.).Canada: University of Toronto Press Incorporated, 2004.

[12]M. W. Galbraith, "Adult learning methods: A guide for effective instruction," Malabar, FL: Krieger Publishing Company, 1991.

[13]L. M. Zinn, "Identifying your philosophical orientation," In M. Galbraith (Ed), Adult learning methods (pp. 39-77). Malabar, FL: Krieger Publishing Company, 1991.

[14]J. W. Apps, "Foundation for effective teaching," In E. Hayes (Ed.), Effective teaching styles (pp. 17-27). San Francisco: Jossey-Bass, Inc, 1989.

[15]P. Friedman, and R. Alley, "Learning/teaching styles: Applying the principles," Theory into Practice, vol. 23, pp. 77-81, 1984.

[16]A. F. Gregorc, "An adults guide to style," Maynard, MA: Gabriel Systems, Inc, 1977.

[17]L. A. Bonham, "Using learning style information, too," In E. Hayes (Ed.), Effective teaching styles (pp. 29-40). San Francisco, CA: Jossey-Bass, 1989.

[18]M. Terry, "Translating learning style theory into university teaching practices: an article based on Kolb's experiential learning model," Journal of college reading and learning, vol. 32, no. 1, pp.68-85, 2001.

[19]M. Woolhouse, and T. Blaire, "Learning styles and retention and achievement on a two-year A-level programme in a further education college," Journal of Further and Higher Education, vol. 27, no. 3, pp. 257-269, 2003.
[20] W. L. Stitt-Gohdes, "Business Education Students. Preferred Learning Styles and Their Teachers. Preferred Instructional Styles: Do They Match?" Delta Pi Epsilon Journal, vol. 43, no. 3, pp. 137151, 2001.

[21]J. Hayes, and C. W. Allinson, "Learning Styles and Training and Development in Work Settings: Lessons from Educational Research," Educational Psychology, vol. 17, no. 1-2, pp. 185-193, 1997.

[22]B. Pithers, "An Aspect of Vocational Teachers. Cognitive Style: Field Dependence-Field Independence," Australian and New Zealand Journal of Vocational Education Research, vol. 9, no. 2, pp. 47-60, 2001.

[23]S. Caudron, "Learners Speak Out. What Actual Learners Actually Think of Actual Training," Training and Development, vol. 54, no. 4, pp. 5257,2000

[24] W. L. Stitt-Gohdes, T. B. Crews, and M. McCannon, "Business Teachers . Learning and Instructional Styles,"Delta Pi Epsilon Journal, vol. 41, no. 2, pp. 71-88, 1999.

[25]J. M. Glenn, "Teaching the Net Generation," Business Education Forum, vol. 54, no. 3, pp. 6-14, 2000.

[26] W. L. Stitt-Gohdes, "Student Teachers and Their Students: Do Their Instructional and Learning Preferences Match?" Business Education Forum, vol. 57, no. 4, pp. 22-27, 2003.

[27]M. Delahoussaye, "The Perfect Learner: An Expert Debate on Learning Styles," Training, vol. 39, no.5, pp. 28-36, 2000.

[28]R. T. Pithers, "Cognitive Learning Style: A Review of the Field Dependent-Field Independent Approach," Journal of Vocational Education \& Training, vol. 54, no. 1, pp. 117-132, 2002.

[29]C. R. Nuckles, "Student-Centred Teaching: Making It Work," Adult Learning, vol. 11, no. 4, pp. 5-6, 2000.

[30] J. C. Spoon, and J. W. Schell, "Aligning Student Learning Styles with Instructor Teaching Styles," Journal of Industrial Teacher Education, vol. 35, no. 2, pp. 41-56, 1998.

[31]K. Bain, "What the best college teachers do," Cambridge, MA: Harvard University Press, 2004.

[32]C. R. Beck, "Matching teaching strategies to learning style preferences," Teacher Educator, vol. 37, no. 10, pp. 1-15, 2001.

[33] S. Bull, and X. Ma, "Raising learner awareness of language learning strategies in situations of limited resources," Interactive Learning Environments, vol. 9, no. 2, pp. 171-200, 2001. 
[34]R. M. Felder, and J. E. Spurlin, "Applications, reliability and validity of the Index of Learning Styles," International Journal of Engineering Education, vol. 21, no. 1, pp. 103-112, 2005.

[35] Y. S. Li, P. S. Chen, and S. J. Tsai, “A comparison of the learning styles among different nursing programs in Taiwan: Implications for nursing education," Nurse Education Today, vol. 28, pp. 70-76, 2008.

[36]L. J. Rayneri, B. L. Gerber, and L. P. Wiley, “The relationship between classroom environment and the learning style preferences of gifted middle school students and the impact on levels of performance," Gifted Child Quarterly, vol. 50, no. 2, pp. 104-118, 2006.

[37]A. Woolfolk Hoy, and P. K. Murphy, "Teaching educational psychology to the implicit mind: Understanding and teaching the intuitive mind," Student and Teacher Learning, pp. 145-86, 2001.

[38]L. F. Zhang, "Does student-teacher thinking style match/mismatch matter in students' achievement?" Educational Psychology, vol. 26, no. 3, pp. 395409, 2006.

[39]C. R. Brew, “Kolb's learning style instrument: Sensitive to gender," Educational and Psychological Measurement, vol. 62, no. 2, pp. 373-90, 2002.

[40]M. K. Smith, "Howard Gardner and Multiple Intelligences," The Encyclopedia of Informal Education. $\quad$ Retrieved from http://www.infed.org/thinkers/gardner.htm, 2002

[41] J. Stevenson, and R. Dunn, "Knowledge management and learning styles: Prescriptions for future teachers," College Student Journal, vol. 3, no. 4, pp. 483-490, 2001.

[42]R. Zhenhui, "Matching teaching styles with learning styles in East Asian contexts," The Internet TESL Journal, vol. 7, no. 7, 2001.

[43] N. Ford, and S. Y. Chen, "Matching/mismatching revisited: An empirical study of learning and teaching styles," British Journal of Educational Technology, vol. 32, no. 1, pp. 5-22, 2001.

[44]D. Kember, and L. Gow, "A model of student approaches to learning encompassing ways to influence and change approaches," Instructional Science, vol. 18, pp. 263-288, 1989.

[45]K. Trigwell, M. Prosser, and F. Waterhouse, "Relations between teachers' approaches and students' approaches to learning," Higher Education, vol. 37, pp. 57-70, 1999.

[46] P. Booth, P. Luckett, and R. Mladenovic, "The quality of learning in accounting education: the impact of approaches to learning on academic performance," Accounting Education, vol. 8, no. 4, pp. 277-300, 1999.

[47]P. Marriott, “A longitudinal study of undergraduate accounting students' learning style preferences at two UK universities," Accounting Education: an international journal, vol. 11, no. 1, pp. 43-62, 2002.

[48] N. B. Jones, "Applying learning styles research to improve writing instruction," Paper presented at RELC Seminar on Learners and Language Learning, Singapore, 1997.

[49] W. Littlewood, N. F. Liu, and C. Yu, "Hong Kong tertiary students' attitudes and proficiency in spoken English," RELC Journal, vol. 27, no. 1, pp. 70-88, 1996.

[50]R. M. Felder, G. N. Felder, and E. J. Dietz, "The effects of personality type on engineering student performance and attitude," Journal of Engineering Education, vol. 91, pp. 3-17, 2002.

[51]A. Mulalic, P. Mohd Shah, and F. Ahmad, "Perceptual learning styles of ESL students," European Journal of Social Sciences, vol. 7, no. 3, pp. 101-113, 2009.

[52]K. Ruhnau, "An analysis of learning outcomes of adult students: Learning styles versus teaching styles," Unpublished master's thesis. The Graduate School University of Wisconsin-Stout, Menomonie, WI, 2006.

[53] V. Chislet, and A. Chapman, "VAK learning styles self-test," In http://www.businessballs.com. vakleearningstyleste st.htm, 2005.

[54]R. Oxford, "Language learning styles and strategies," In M. Celce-Murcia (Ed.) Teaching English as a second or foreign language (pp. 359 -366). Boston: Heinle, 2001.

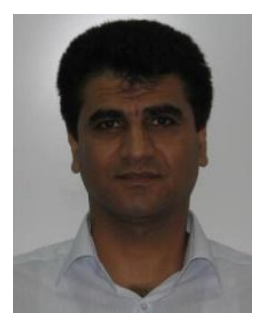

Abbas Pourhosein Gilakjani was born in Roodsar, Iran. The author has received B.A. degree in the field of English Language Translation from the Islamic Azad University of Tonekabon Campus, Mazandaran, Iran. He has also received M.A. degree in the field of Teaching English as a Foreign Language from the Islamic Azad University of Garmsar Campus, Semnan, Iran.

He has been teaching English in the English Translation Department at the Islamic Azad University of Lahijan, Guilan, Iran from 1999 to 2010. He was the Head of English Translation Department from 20072009. He is studying Ph.D. in TESOL at the USM, Malaysia. His publications are: (1) The Effect of 
Information and Communication Technology on Teaching and Learning (India, ELT Weekly Journal, vol.3 Issue\#79 January, 17, 2011. (2) Role of Consciousness in Second Language Acquisition (Finland, TPLS Journal, Issue 5, May, 2011. (3) Why Is Pronunciation So Difficult To Learn? (Canada, ELT Journal, vol. 4, no. 3, September, 2011). (4) Multimedia and Its Effect on the Quality of English Language Teaching (Indonesia, Celt, Vol. 11, No. 1, pp. 14-35, 2011.

His main interests are English pronunciation instruction, speaking skill, listening skill, technology, motivation, and reading comprehension skill.

Mr. Pourhosein Gilakjani is the Faculty Member of the Islamic Azad University of Lahijan, Iran.

\section{APPENDIX:}

\section{VAK Learning Styles Self-Assessment} Questionnaire (Chislett \& Chapman, 2005)

Circle or tick the answer that most represents how you generally behave!

\section{When I operate new equipment I generally: \\ a) read the instructions first \\ b) listen to an explanation from someone who has used it before \\ c) go ahead and have a go, I can figure it out as I use it}

\section{When I need directions for travelling I usually:}

a) look at a map

b) ask for spoken directions

c) follow my nose and maybe use a compass

3. When I cook a new dish, I like to:

a) follow a written recipe

b) call a friend for an explanation

c) follow my instincts, testing as I cook

\section{If I am teaching someone something new, I tend} to:

a) write instructions down for them

b) give them a verbal explanation

c) demonstrate first and then let them have a go

\section{I tend to say:}

a) watch how I do it

b) listen to me explain

c) you have a go

6. During my free time I most enjoy:

a) going to museums and galleries

b) listening to music and talking to my friends

c) playing sport or doing DIY
7. When I go shopping for clothes, I tend to:

a) imagine what they would look like on

b) discuss them with the shop staff

c) try them on and test them out

\section{When I am choosing a holiday I usually:}

a) read lots of brochures

b) listen to recommendations from friends

c) imagine what it would be like to be there

9. If I was buying a new car, I would:

a) read reviews in newspapers and magazines

b) discuss what I need with my friends

c) test-drive lots of different types

10. When I am learning a new skill, I am most comfortable:

a) watching what the teacher is doing

b) talking through with the teacher exactly what I'm supposed to do

c) giving it a try myself and work it out as I go

11. If I am choosing food off a menu, I tend to:

a) imagine what the food will look like

b) talk through the options in my head or with my partner

c) imagine what the food will taste like

\section{When I listen to a band, I can't help:}

a) watching the band members and other people in the audience

b) listening to the lyrics and the beats

c) moving in time with the music

\section{When I concentrate, I most often:}

a) focus on the words or the pictures in front of me

b) discuss the problem and the possible solutions in my head

c) move around a lot, fiddle with pens and pencils and touch things

14. I choose household furnishings because I like:

a) their colours and how they look

b) the descriptions the sales-people give me

c) their textures and what it feels like to touch them

15. My first memory is of:

a) looking at something

b) being spoken to

c) doing something

16. When I am anxious, I:

a) visualise the worst-case scenarios

b) talk over in my head what worries me most

c) can't sit still, fiddle and move around constantly

17. I feel especially connected to other people because of:

a) how they look 
b) what they say to me

c) how they make me feel

18. When I have to revise for an exam, I generally: a) write lots of revision notes and diagrams

b) talk over my notes, alone or with other people

c) imagine making the movement or creating the formula

\section{If I am explaining to someone I tend to:}

a) show them what I mean

b) explain to them in different ways until they understand

c) encourage them to try and talk them through my idea as they do it

\section{I really love:}

a) watching films, photography, looking at art or people watching

b) listening to music, the radio or talking to friends

c) taking part in sporting activities, eating fine foods and wines or dancing

21. Most of my free time is spent:
a) watching television
b) talking to friends
c) doing physical activity or making things

22. When I first contact a new person, I usually:

a) arrange a face to face meeting

b) talk to them on the telephone

c) try to get together whilst doing something else, such as an activity or a meal

\section{I first notice how people:}

a) look and dress

b) sound and speak

c) stand and move

\section{If I am angry, I tend to:}

a) keep replaying in my mind what it is that has upset me b) raise my voice and tell people how I feel

c) stamp about, slam doors and physically demonstrate my anger

\section{I find it easiest to remember:}
a) faces
b) names
c) things I have done

26. I think that you can tell if someone is lying if:

a) they avoid looking at you

b) their voices changes

c) they give me funny vibes

27. When I meet an old friend:

a) I say "it's great to see you!"

b) I say "it's great to hear from you!"

c) I give them a hug or a handshake

\section{I remember things best by:}

a) writing notes or keeping printed details

b) saying them aloud or repeating words and key points in my head

c) doing and practising the activity or imagining it being done

29. If I have to complain about faulty goods, I am most comfortable:
a) writing a letter
b) complaining over the phone
c) taking the item back to the store or posting it to head office

\section{I tend to say:}

a) I see what you mean

b) I hear what you are saying

c) I know how you feel

\section{Good Luck}

